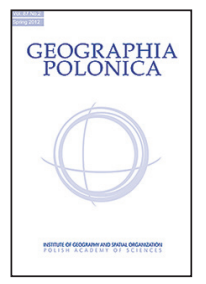

\title{
THE GEOGRAPHY OF JAPANESE DIRECT INVESTMENT IN THE U.S. AUTOMOTIVE SECTOR: A REVIEW OF THE STATE OF KNOWLEDGE AND SOME IDEAS FOR FUTURE RESEARCH
}

\author{
Neil Reid \\ Chair of the IGU Commission on The Dynamics of Economic Spaces \\ The University of Toledo \\ Department of Geography and Planning \\ Ohio 43606, Toledo: USA \\ e-mail: neil.reid@utoledo.edu
}

\begin{abstract}
Beginning in the mid-1980s Japanese manufacturing companies began to invest heavily in U.S. production capacity. This was partly a response to a weakening U.S. dollar and trade protectionist measures imposed by the U.S. government. Japanese investment in U.S. production capacity continues unabated today. As more and more Japanese manufacturers started manufacturing their products in the United States there was an interest among geographers to understand the spatial dynamics of this investment. Much of this investment was directed towards the automotive sector. Given the large amount of investment that flowed into the automotive sector the purpose of this is to summarize three decades of scholarly research on Japanese direct investment in this sector.
\end{abstract}

\section{Key words}

Japanese direct investment $\bullet$ automotive sector $\bullet$ spatial dynamics $\bullet$ agglomeration economies $\bullet$ labour

\section{Introduction}

The late-1980s witnessed the beginning of scholarly interest in Japanese Direct Investment in the U.S. manufacturing (JDIUSM) sector. This interest was sparked by the growing presence of Japanese-owned manufacturing facilities in the United States. Today, Japan is fourth largest foreign direct investor in the U.S. manufacturing sector, behind the United Kingdom, the Netherlands, and Switzerland. Japanese companies have \$93.4 billion invested in U.S. manufacturing facilities. This represents $10.4 \%$ of total foreign direct investment (FDI) in U.S. manufacturing (Tab. 1). Japanese manufacturing companies have invested in a broad portfolio of industries. However the transportation equipment 
sector is the primary target for Japanese investors. This sector accounts for 40.8\% of JDIUSM followed by chemicals (16\%) and machinery (12\%) (Tab. 2). Japanese direct investment in the transportation equipment sector is largely driven by its investment in the automobile assembly and auto parts industry. Japan's manufacturing presence in the United States has enjoyed steady growth over the last three decades growing from a modest \$2.9 billion in 1980 to $\$ 93.4$ billion in 2012 (Fig. 1). Prior to the mid-1980s there was relatively little Japanese direct investment in the U.S. manufacturing sector. Up until then Japanese manufacturers had very successfully accessed the U.S. market via the process of exporting. A number of factors including the imposition of quotas and tariffs on the import of Japanese manufactured goods and the weakening of the U.S. dollar relative to the Japanese yen made the U.S. market increasingly expensive for Japanese manufacturers to access via exporting. As a result Japanese manufacturers with a desire to sell their product in the American market decided to manufacture their products in the United States.

Table 1. Foreign direct investment in the U.S. Manufacturing Sector, 2012

\begin{tabular}{|l|c|c|}
\hline \multicolumn{1}{|c|}{ Country } & \$Billions & Share (\%) \\
\hline United Kingdom & 137.6 & 15.3 \\
Netherlands & 118.3 & 13.2 \\
Switzerland & 106.6 & 11.9 \\
Japan & 93.4 & 10.4 \\
France & 75.8 & 8.4 \\
Luxembourg & 73.7 & 8.2 \\
Germany & 67.4 & 7.5 \\
Belgium & 55.3 & 6.1 \\
Canada & 39.9 & 4.4 \\
Sweden & 29.0 & 3.3 \\
Other & 101.9 & 11.3 \\
\hline Total & 898.3 & 100.0 \\
\hline
\end{tabular}

Note: Investment numbers are on a historical-cost basis.

Source: Ibarra-Caton (2013).
Table 2. The composition of Japanese direct investment in the U.S. Manufacturing Sector, 2012

\begin{tabular}{|c|c|c|}
\hline Sector & \$ Billions & Share (\%) \\
\hline $\begin{array}{l}\text { Transportation } \\
\text { Equipment }\end{array}$ & 38,121 & 40.8 \\
\hline Chemicals & 14,914 & 16.0 \\
\hline Machinery & 11,259 & 12.0 \\
\hline $\begin{array}{l}\text { Computers } \\
\text { \& Electronic } \\
\text { Products }\end{array}$ & 7,314 & 7.8 \\
\hline $\begin{array}{l}\text { Primary \& Fabri- } \\
\text { cated Metals }\end{array}$ & 4,547 & 4.9 \\
\hline Food & 2,055 & 2.2 \\
\hline $\begin{array}{l}\text { Electrical Equip- } \\
\text { ment, Appliances } \\
\text { \& Components }\end{array}$ & 1,662 & 1.8 \\
\hline Other & 13,525 & 14.5 \\
\hline Total & 93,398 & 100.0 \\
\hline
\end{tabular}

Note: Investment numbers are on a historical-cost basis.

Source: Ibarra-Caton (2013).

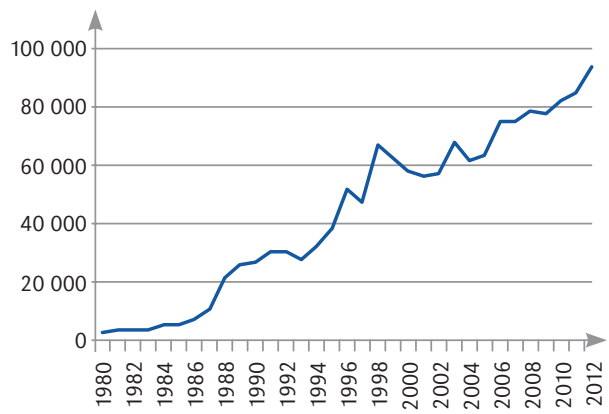

Figure 1. Growth of Japanese direct investment in the U.S. Manufacturing Sector, 1980-2012 (in 2012 dollars)

Note: Investment numbers are displayed in 2012 dollars.

Source: Bureau of Economic Analysis (1986, 1988, 1991); Belli (1984); Ibarra-Caton (2013); Lowe (1998, 2001, 2004, 2007, 2011).

The growth of JDIUSM has, not surprisingly, attracted a lot of interest from academic scholars, including geographers. As Japanese manufacturers raced to have a manufacturing 
presence in the United States, American academics scrambled to make sense of this phenomenon. Since 1988 there have been 27 academic journal articles and book chapters that dealt with some aspect of the geography of JDIUSM. The primary objective of this paper is to assess the state of knowledge with respect to the spatial dynamics of JDIUSM. As such this is a review paper. Its main purpose is to review and synthesize existing literature, not to present new data or analysis on the topic. Such a review is useful because while scholarly interest in JDIUSM appears to have waned the growth of this investment has continued. From a research perspective it might be useful to take stock, to assess what we know, and to suggest potential avenues for future research. Identifying some knowledge gaps may reinvigorate interest in re-opening geographic inquiry.

Following this introduction the remainder of this paper is divided into three sections. In the second section the pattern of scholarship on JDIUSM is described. This section clearly demonstrates a strong bias towards scholarly interest in Japanese direct investment in the automobile industry. In the third section the motivations for JDIUSM are examined within the context of two major theories of foreign direct investment - market imperfections and oligopolistic-reaction. In the third section the locational determinants and spatial dynamics of JDIUSM are explored with an emphasis placed on the role of agglomeration economies and labour costs. In the fourth, and concluding section an assessment of the research on JDIUSM is provided and some suggestions for future research are presented.

\section{Academic interest in the Geography of JDIUSM}

This main focus of this paper is 27 academic journal articles and book chapters published between 1988 and 2008 that dealt in a significant way with some aspect of the geography of JDIUSM (Tab. 3). Twenty (74\%) of these

Table 3. Journal articles and book chapters on the Geography of JDIUSM, 1988-2008

\begin{tabular}{|c|c|c|c|c|c|}
\hline Author(s) & Date & Publication outlet & $\begin{array}{c}\text { Primary data } \\
\text { source }\end{array}$ & $\begin{array}{l}\text { Analytical } \\
\text { technique }\end{array}$ & Industry focus \\
\hline Cole and Deskins & 1988 & $\begin{array}{l}\text { California } \\
\text { Management } \\
\text { Review }\end{array}$ & Author survey & Ratio analysis & Auto industry \\
\hline $\begin{array}{l}\text { Mair, Florida, } \\
\text { and Kenney }\end{array}$ & 1988 & $\begin{array}{l}\text { Economic } \\
\text { Geography }\end{array}$ & Various & Mapping & Auto industry \\
\hline Chang & 1989 & $\begin{array}{l}\text { Professional } \\
\text { Geographer }\end{array}$ & JEI & OLS regression & Manufacturing \\
\hline $\begin{array}{l}\text { Reid } \\
\text { and Ó hUallacháin }\end{array}$ & 1990 & $\begin{array}{l}\text { Professional } \\
\text { Geographer }\end{array}$ & JEl & Mapping & Auto industry \\
\hline Reid & 1990 & $\begin{array}{l}\text { Industrial } \\
\text { Relations Journal }\end{array}$ & JEl & Mapping & Auto industry \\
\hline $\begin{array}{l}\text { Florida } \\
\text { and Kenney }\end{array}$ & 1991 & Book chapter & $\begin{array}{l}\text { JEI, JAMA, } \\
\text { USGAO, USITC, } \\
\text { \& author survey }\end{array}$ & Mapping & Auto industry \\
\hline $\begin{array}{l}\text { Kenney } \\
\text { and Florida }\end{array}$ & 1991 & $\begin{array}{l}\text { Technology } \\
\text { Review }\end{array}$ & Undocumented & Mapping & Auto industry \\
\hline Reid & 1991 & Book chapter & JEl & Mapping & Manufacturing \\
\hline Rubenstein & 1991 & Book chapter & WAY & Mapping & Auto industry \\
\hline
\end{tabular}




\begin{tabular}{|c|c|c|c|c|c|}
\hline Author(s) & Date & Publication outlet & $\begin{array}{l}\text { Primary data } \\
\text { source }\end{array}$ & $\begin{array}{l}\text { Analytical } \\
\text { technique }\end{array}$ & Industry focus \\
\hline $\begin{array}{l}\text { Doeringer } \\
\text { and Terkla }\end{array}$ & 1992 & $\begin{array}{l}\text { Economic } \\
\text { Development } \\
\text { Quarterly }\end{array}$ & JEI & $\begin{array}{l}\text { Shift-share } \\
\& \text { correlation } \\
\text { analyses }\end{array}$ & Manufacturing \\
\hline $\begin{array}{l}\text { Elhance } \\
\text { and Chapman }\end{array}$ & 1992 & $\begin{array}{l}\text { Growth } \\
\text { and Change }\end{array}$ & Author survey & Mapping & Auto Industry \\
\hline $\begin{array}{l}\text { Florida } \\
\text { and Kenney }\end{array}$ & 1992 & $\begin{array}{l}\text { Economic } \\
\text { Geography }\end{array}$ & JEI, JSIC, \& JISA & Mapping & $\begin{array}{l}\text { Steel/Auto } \\
\text { industry }\end{array}$ \\
\hline $\begin{array}{l}\text { Kenney } \\
\text { and Florida }\end{array}$ & 1992 & $\begin{array}{l}\text { Journal of } \\
\text { the American } \\
\text { Planning } \\
\text { Association }\end{array}$ & $\begin{array}{l}\text { JEI, JAMA, } \\
\& \text { USTIC }\end{array}$ & Mapping & Auto industry \\
\hline $\begin{array}{l}\text { Ó hUallacháin } \\
\text { and Reid }\end{array}$ & 1992 & $\begin{array}{l}\text { Professional } \\
\text { Geographer }\end{array}$ & USDOC & $\begin{array}{l}\text { OLS regression, } \\
\text { location quotient, } \\
\text { \& mapping }\end{array}$ & Manufacturing \\
\hline Woodward & 1992 & $\begin{array}{l}\text { Southern } \\
\text { Economic Journal }\end{array}$ & JEl & $\begin{array}{l}\text { Conditional logit } \\
\text { analysis }\end{array}$ & Manufacturing \\
\hline $\begin{array}{l}\text { Perrucci } \\
\text { and Kong }\end{array}$ & 1994 & Book chapter & Not applicable & OLS regression & Auto industry \\
\hline Smith and Florida & 1994 & $\begin{array}{l}\text { Journal of Urban } \\
\text { Economics }\end{array}$ & Author database & $\begin{array}{l}\text { Tobit, poisson, } \\
\text { and negative } \\
\text { binomial } \\
\text { regression } \\
\text { analyses }\end{array}$ & Auto industry \\
\hline $\begin{array}{l}\text { Head, Ries, } \\
\text { and Swenson }\end{array}$ & 1995 & $\begin{array}{l}\text { Journal of } \\
\text { International } \\
\text { Economics }\end{array}$ & JEl & $\begin{array}{l}\text { Conditional } \\
\text { logit analysis } \\
\text { and mapping }\end{array}$ & Manufacturing \\
\hline Klier & 1995 & $\begin{array}{l}\text { Economic } \\
\text { Perspectives }\end{array}$ & ELM & $\begin{array}{l}\text { Wilcoxin test } \\
\text { and mapping }\end{array}$ & Auto industry \\
\hline Reid & 1995 & Regional Studies & Author survey & $\begin{array}{l}\text { OLS regression } \\
\text { analysis }\end{array}$ & Manufacturing \\
\hline $\begin{array}{l}\text { Reid, Solocha, } \\
\text { and Ó hUallacháin }\end{array}$ & 1995 & Book chapter & JEl & Mapping & Auto Industry \\
\hline $\begin{array}{l}\text { Ó hUallacháin } \\
\text { and Reid }\end{array}$ & 1997 & Regional Studies & JEl & $\begin{array}{l}\text { OLS and tobit } \\
\text { regression analysis } \\
\text { and location } \\
\text { quotients }\end{array}$ & Manufacturing \\
\hline Klier & 1999 & $\begin{array}{l}\text { Economic } \\
\text { Perspectives }\end{array}$ & ELM & $\begin{array}{l}\text { Wilcoxin test } \\
\text { and mapping }\end{array}$ & Auto industry \\
\hline Klier & 2000 & $\begin{array}{l}\text { Journal } \\
\text { of Regional } \\
\text { Analysis \& Policy }\end{array}$ & ELM & $\begin{array}{l}\text { Radii of gyration } \\
\text { and mapping }\end{array}$ & Auto industry \\
\hline Liker and $\mathrm{Wu}$ & 2006 & Book chapter & Author survey & ANOVA & Auto industry \\
\hline $\begin{array}{l}\text { Klier } \\
\text { and Rubenstein }\end{array}$ & 2008 & Book chapter & ELM & Mapping & Auto industry \\
\hline $\begin{array}{l}\text { Klier } \\
\text { and Rubenstein }\end{array}$ & 2008 & Book chapter & ELM & Mapping & Auto industry \\
\hline
\end{tabular}


articles/chapters were written during the 1990-1999 period. The decade of the 1990s clearly represents the zenith of academic interest in the geography of JDIUSM. In the five-year period since 1999 only 4 articles/ book chapters on JDIUSM have appeared in print (Fig. 2). The papers listed in Figure 2 represent only those articles that are overtly geographic and address the topic of Japanese direct investment in the U.S. manufacturing sector. There are many other papers written on JDIUS whose perspective is nongeographic as well as papers that are geographic but whose focus is outside of the United States. A number of these works are cited when their contents are relevant to helping understand the spatial dynamics of Japanese direct investment in the U.S. manufacturing sector.

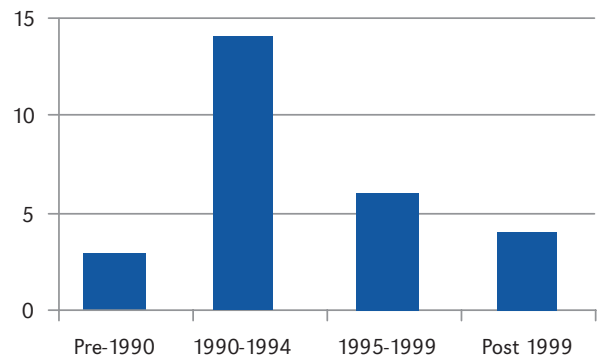

Figure 2. Number of academic publications on the Geography of new Japanese direct investment in the U.S. Manufacturing Sector, 1988-2008

Japanese direct investment (JDI) in the American automobile industry has dominated the geographic research agenda. Nineteen $(70 \%)$ of the 27 articles/chapters have focused specifically on JDI in the American automobile assembly and auto part industry. The other eight have not focused upon any particular industry. Rather, they have examined JDIUSM in general (Tab. 2). This automotive bias is understandable when one considers three facts. First, automotive-related investment dominates Japanese direct investment in the United States (JDIUS) (Tab. 1).
Second, Japanese auto-related investment, more than any other sector, is dominated by greenfield investments (Reid et al. 1995). Greenfield investments necessitate an actual location decision. There is, on the other hand, no location decision associated with acquired investments. Acquired investments involve the takeover of existing (and hence already located) facilities. Studying Japanese investments in the automotive sector, therefore provides, geographers with the opportunity to study the location decision-making process of Japanese direct investors. Third, the automotive industry is the quintessential American industry and America the world's quintessential automobile society. The socio-economic impact of the automobile has been greater in the United States than in any other country. The decision by Japanese automakers and their component parts suppliers to invest in automotive production capacity in the United States, therefore, involved 'invading' an industry that has a special place in the hearts and minds of the American people.

\section{Japanese direct investment in the United States: Motivators}

The increase in Japanese direct investment in the U.S. manufacturing sector is one that many Japanese manufacturers would have preferred not to have happened (Sayer 1986; Dicken 1988). Indeed, Trevor (1983) has referred to Japanese manufacturers as the "reluctant multinationals". Much of this reluctance stemmed from potential problems associated with moving production from a familiar socio-economic environment to an unfamiliar one. Issues associated with foreign direct investment include having to hire and train workers who are unfamiliar with Japanese production methods and work practices. Despite this reluctance Japanese manufacturers have invested heavily in U.S. production capacity since the mid-1980s. Two theories of foreign direct investment - market imperfections theory and oligopolistic-reaction theory - help explain the rise and growth of JDIUSM. 


\section{Market imperfections}

The existence of market imperfections helps to explain a significant amount of JDIUSM. Three main sources of market imperfections seem to have driven this investment - fluctuations in the yen-dollar ratio, tariffs and quotas, and the separation of markets for both material and information inputs.

With respect to the yen-dollar ratio, starting in 1985, the general trend has been the relative strengthening of the Japanese yen against the U.S. dollar. For example, in 1985 the yen-dollar ratio was $154: 1$, by 1988 it was 127:1, and by 2011 it was $82: 1$ (Fig. 3). This raised the cost of imported Japanese goods for American consumers while at the same time decreasing the costs of American land and manufacturing facilities to potential Japanese investors. Tsukazaki (1987) argued that it is difficult to quantify the extent to which the yen's rising value accelerated overseas direct investment by Japanese companies but there is little doubt that it is a significant factor (Flynn 1986; Tyebjee 1988).

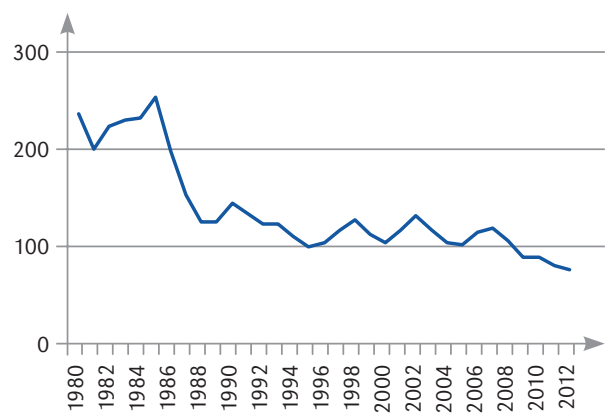

Figure 3. Yen-Dollar exchange rate, 1980-2012

Note: Exchange rates are for January of each year. Source: Bank of Japan (http://www.stat-search. boj.or.jp/ssi/mtshtml/m_en.html).

In addition to the appreciating value of the yen against the dollar, rising protectionism on the part of the United States also induced many Japanese manufacturers to establish production capacity in the United States (Sayer
1986). Over the years a large number of Japanese exporters have faced tariffs and quotas and establishing U.S. production capacity has allowed them to circumvent them (Franko 1983). Indeed, since the 1960s the tariffs and quotas were imposed on a wide range of Japanese products including automobiles (Rubenstein 1986), steel (Kawahito 1981), colour television sets (Ozawa 1979), computers (Lewis 1989) and textiles (Gross 1989).

Japanese industry has a unique organizational structure, dominated by corporate groups whose member firms have close ownership, business, and technological relationships. Corporate groups are a response to imperfections in the goods, capital, information, and labor markets. These imperfections are circumvented by internalizing, within corporate groups, the markets for inputs to the production process. With respect to material inputs Japanese manufacturers with production facilities in the United States often prefer to procure material inputs from other Japanese companies who are within the same corporate group and/or who provide them with material inputs in Japan. Securing material inputs from established and trusted suppliers allows Japanese manufacturers to better control both quality and price. In the case of the automotive industry these parts are often delivered on a just-in-time basis (see below). The desire to be supplied by established suppliers explains why many Japanese parts suppliers (e.g. within the automobile industry) have established production facilities in the United States. There is further discussion of corporate group membership and its spatial implications below.

\section{Oligopolistic reaction}

As early as 1979 Ozawa suggested that oligopolistic manoeuvring was a major reason for large amounts of the early Japanese direct investment in the U.S. manufacturing sector. The basic premise of the theory is that competitors in industries with an oligopolistic structure react to each other's strategic moves by engaging in mimicking 
behaviour (Knickerbocker 1969). For example, Sony began manufacturing colour television sets in San Diego, California in 1972 (Yoshino 1976). They were quickly followed to the United States by other Japanese colour television manufacturers and by 1988 there were twelve Japanese companies manufacturing colour televisions in the United States (MacKnight 1989). Yoshino (1976) claimed that Sony's decision to manufacture colour television sets in the United States was perceived by other Japanese television manufacturers as a threat to their share of the U.S. market. This threat was mitigated by Sony's major competitors investing in U.S. production capacity. There are limitations, however, to the oligopolistic reaction model as an explanatory tool for understanding JDIUSM. First, although it may explain why some firms (i.e. the followers) invest in U.S. production capacity it fails to explain why the original investor in a sector decided to do so. Second, the oligopolistic reaction model assumes that foreign direct investors are large firms who are members of industries that have an oligopolistic structure. While there are a number of large Japanese companies with production capacity in the United States (e.g. the Japanese automakers) a distinctive characteristic of Japanese direct investment in U.S. manufacturing is the dominance of small and medium-sized firms that operate markets that resemble a perfectly competitive structure.

\section{Japanese direct investment in the United States: Locational determinants and spatial dynamics}

\section{Agglomeration economies and JIT}

Geographic research on JDIUSM has focused upon describing the spatial distribution and identifying the locational determinants of this investment. Prior to 1980 JDIUS was geographically concentrated in the Pacific Coast states. California (38\% of total JDIUSM) and, to a lesser extent, Alaska (9\%) were particularly favoured destinations of early Japanese direct manufacturing investment (Reid 1991).
Ó hUallacháin and Reid (1992) attributed this Pacific coast preference to what is commonly known in the foreign direct investment literature as the border effect. The border effect hypothesis suggests that foreign direct investors will focus their investment in countries that share a border with their home country. While Japan does not share a physical border with the United States the states that have a Pacific coastline can be considered the equivalent of border states. The preference for countries with a shared border occurs for a number of reasons including the fact that time zone differences with the home country are minimized, travel distances in the event of the need to make a trip home for business or social reasons are lessened, and neighbouring countries (compared to non-neighbouring countries) are more likely to contain larger numbers of immigrants from the home country (Heller \& Heller 1974; Haigh 1989). For example, Californian cities such as Los Angeles have significant numbers of residents whose ethnicity is Japanese (Allen \& Turner 1996). During the 1980s, while the border effect was still shown to be influential, JDIUSM became more geographically dispersed (Ó hUallacháin \& Reid 1992, 1997). Although the Pacific Coast (particularly California) continued to receive large volumes of Japanese direct investment during the second half of the 1980s the region that was to become known as the Auto Alley (Alabama, Illinois, Indiana, Kentucky, Michigan, Mississippi, Ohio, Tennessee) emerged as the primary recipient of JDIUSM (Klier \& Rubenstein 2008b) (Figure 4). ${ }^{1}$ The influx of Japanese automobile assembly plants and automobile component parts makers was the catalyst behind this geographic shift. During the 1980s the Auto Alley received $43 \%$ of JDIUSM (Reid 1991). An Auto Alley location allowed Japanese automakers to minimize the costs of distributing assembled automobiles to the

\footnotetext{
1 Prior to 2000 the Auto Alley comprised the states of Illinois, Indiana, Kentucky, Michigan, Ohio, and Tennessee. Due to changing Japanese investment patterns the states of Alabama and Mississippi were added to the Auto Alley in the post-2000 period.
} 
American market (Reid 1990). Many Japanese auto part makers likewise located in the northern half of the Auto Alley. They did so, it has been argued, in order to be close to the Japanese assembly plants. Close geographic proximity to the automobile assembly plants facilitated just-in-time delivery of component parts (Florida \& Kenney 1991a).

The growth of Japanese automobile investment in the Auto Alley has changed over time. There are 13 Japanese automobile assembly plants in the United States, 8 of which were constructed before 2000 and 5 of which were constructed after 2000. There is a very distinctive geography to the pre- and post- 2000 assembly plants. All of those constructed prior to 2000 are located in the northern half of the Auto Alley while 3 of the 5 constructed after 2000 are in the southern half of the Auto Alley, one is in the northern half of the Auto Alley, and one is completely outside of it (Fig. 4).
A significant theme permeating geographic research on JDIUSM has been assessing the role of agglomeration economies in influencing its spatial distribution. Agglomeration economies have long been invoked as a key explanatory factor in the spatial clustering of manufacturing in general and foreign direct investment in particular (see for example, Shaver \& Flyer 2000; He 2003; Crozet et al. 2004). The evidence presented in these studies provides mixed support for the proposition that agglomeration economies are a critical factor in the location decisions made by Japanese manufacturers. Within the context of JDIUSM three distinct types of agglomeration economies have been identified. First, agglomeration economies are defined in terms of the extent to which the spatial distribution of JDIUSM parallels the spatial distribution of domestic manufacturing investment (hereafter known as TYPE I agglomeration). Second, they are defined in terms of the

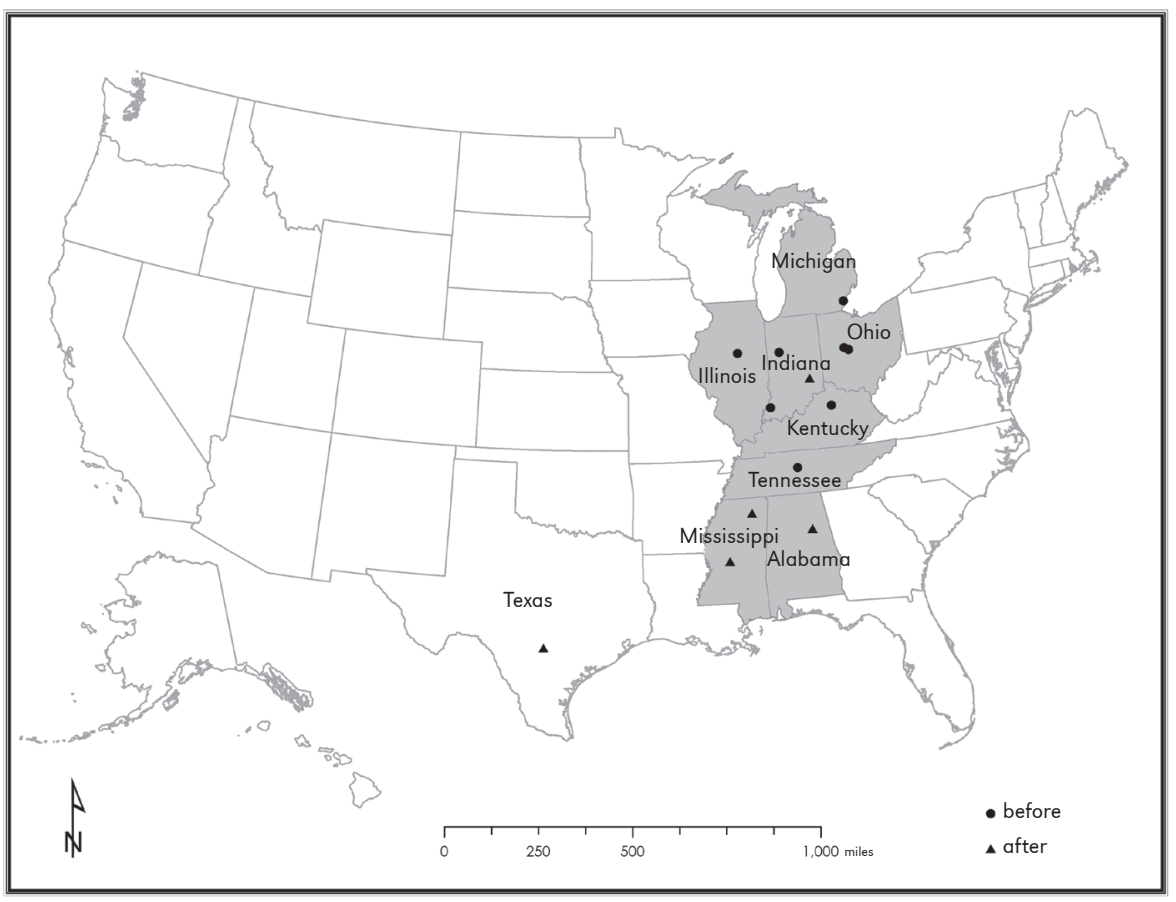

Figure 4. Japanese auto assembly plants opened pre- and post-2000 
extent to which the spatial distribution of new JDIUSM parallels the spatial distribution of existing JDIUSM (TYPE II agglomeration). Third, they are defined in terms of the extent to which the spatial distribution of JDIUSM in a specific manufacturing sector (e.g. automobiles) is driven by the need of customers and suppliers to be in close geographic proximity to each other (TYPE III agglomeration).

There are a number of studies that find support for TYPE I agglomeration. Chang (1989) noted that JDIUSM during the early 1980s (1982-1986) was geographically concentrated in states experiencing a general growth of manufacturing. Ó hUallacháin and Reid (1992), likewise, for the period 1980-1987, found Japanese manufacturers locating in states with large amounts of domestic manufacturing. Both of these studies failed, however, to disaggregate JDIUSM by mode of entry - acquisition or greenfield. An acquisition refers to a situation where a Japanese investor purchases an existing manufacturing facility while a greenfield investment involves construction a new manufacturing facility. Such disaggregation makes sense in light of the fact that Japanese acquisitions are constrained by the geographic distribution of acquisition opportunities. Such constraints are not, by definition, placed upon greenfield investments.

Recognizing the need to disaggregate JDIUSM by mode of entry Ó hUallacháin and Reid (1997) conducted separate analyses for acquired and greenfield Japanese manufacturing plants. Not surprisingly, they found the geographic distribution of Japanese acquisitions during the 1970s, 1980s, and early 1990s to be influenced by the geographic distribution of domestic manufacturing. Similarly, they found that the distribution of domestic manufacturing to influence Japanese greenfield investments during the 1970s and 1980s. By the early 1990s, however, the geographic distribution of domestic manufacturing was no longer influencing the geography of Japanese greenfield investments.

TYPE II agglomeration has been the subject of one study. Ó hUallacháin and Reid (1997) found some evidence that Japanese manufacturing acquisitions during the 1970s were influenced by the geographic distribution of JDIUSM. During the 1980s and early 1990s, however, there was no evidence to support this. In the case of greenfield investments Ó hUallacháin and Reid (1997) found no evidence that these investments were being influenced by the geographic distribution of JDIUSM during the 1970s and 1980s. They did, however, find evidence that the geographic distribution of JDIUSM influenced Japanese greenfield investments during the early 1990s. In a study of JDI in Europe Gross et al. (2005) found that during the 1970s Japanese manufacturing investment appeared to be attracted by the existence of other Japanese manufacturing investment. By the mid-1980s, however, the location of Japanese manufacturing investment was more strongly influenced by the presence of Japanese service investment than Japanese manufacturing investment.

Of the three categories of agglomeration economies TYPE III are the most extensively studied. A study by Head et al. (1995) suggested that TYPE III agglomeration effects were operating across a wide range of sectors, not just in the oft-quoted automotive industry. It is in the automotive industry, however, that the phenomenon of TYPE III agglomeration economies has been most extensively studied. Many of these studies suggest the existence of very strong agglomeration economies with respect to Japan's automotive presence in the United States. These agglomerations are characterized by close geographic proximity between an assembly plant and its suppliers. This proximity, it has been argued, facilitates the smooth functioning of just-in-time (JIT) manufacturing systems. Under JIT parts are delivered to the point of final assembly just in time for incorporation into the manufacturing process. Parts can be delivered as frequently as every two hours (Florida \& Kenney 1991b). Kenney and Florida (1992) suggest that JIT necessitates close spatial proximity between customers and suppliers. The result, they argue, is a geographically clustered pattern of assemblers and suppliers. Smith and 
Florida (1994), using regression analysis, found support for the hypothesis that proximity to a Japanese assembly plant is a key site selection criteria for Japanese auto parts suppliers. They also found, however, that the existence of domestic assembly plants might be influencing the location decisions of Japanese part suppliers. This latter finding suggests that the agglomeration economies experienced by Japanese auto parts suppliers might extend beyond the advantages of being in close geographic proximity to Japanese assembly plants.

In an early study on the spatial implications of JIT Kenney and Florida (1992) found its use to be widespread among Japanese automotive companies in the United States. Eighty percent of first-tier suppliers and $43 \%$ of second-tier suppliers deliver component parts according to a JIT schedule. First tier suppliers sell and deliver directly to the automobile assembly plants while second tier suppliers supply first tier suppliers. Furthermore, Kenney and Florida (1992) found that $41 \%$ of first-tier suppliers are located within a two-hour drive of their major customers. Indeed, proximity to automobile assembly plants was the most important site selection criteria for $90 \%$ of Japanese automobile component parts makers (Kenney \& Florida 1992). In addition to facilitating the delivery of parts Florida and Kenney (1991b) also suggest that geographic proximity makes it easier for engineering personnel to travel between plants to discuss engineering and production issues.

An interesting twist on agglomeration in the automotive industry concerns the potential influence of Japanese corporate groups and networks. Reid et al. (1995) hypothesized that Japanese automotive agglomerations in the United States might be geographically organized around corporate group membership. In other words Japanese automakers in the United States do not just attain their component parts from any Japanese supplier. Rather, they obtain them from suppliers who are members of the same corporate group (keiretsu).
Purchasing component parts from corporate group members ensures the delivery of high quality component parts according to quality and delivery specifications established by the automakers themselves. Rubenstein (1991) noted that Japanese automakers often ask key suppliers to follow them to the United States to provide them with component parts, while a survey by Kenney and Florida (1992) found that the desire to maintain an existing relationship with a Japanese automaker was the primary reason that Japanese component parts makers decided to establish U.S. production capacity. Ó hUallacháin (1993) agued that corporate group ties influenced the location decisions of Japanese steel producers in the United States. Despite suggestions that corporate group membership might influence the location of JDIUSM there is only limited statistical evidence to support this hypothesis, Indeed the only statistical evidence was presented by Head et al. (1995) who found that the location of Japanese auto component parts makers is influenced by the need to be in close geographic proximity to assembly plants who are members of the same corporate group. Martin et al. (1995), however, found that Japanese auto makers in the United States re-established only 26\% of the supply linkages that they had in Japan. Those that were re-established tended to be those that were strong in Japan. At the same time research has shown that suppliers have a lot more independence in seeking new business relationships than previous studies have suggested (Martin et al. 1995). This is a finding supported by Ngido (2011) who questions the conventional wisdom that customer-supplier relationships in the Japanese automotive industry are ones in which the customer tends to be dominant and the supplier tends to be captive. In terms of the benefits of working with an existing partner it has been shown that long-established customersupplier relationships are most effective in facilitating the transfer of more complex and higher-level knowledge and technology (Kotabe et al. 2003). In an intriguing study Blonigen et al. 2005 examined the location 
decisions of companies who are in different industries but are members of the same corporate group (horizontal, as opposed to vertical, keiretsu). They found evidence that such companies tended to be influenced by the location decisions of other corporate group members suggesting that networking and information externalities were responsible. However, this study was conducted at the international scale and so we do not know if the same processes are at work and the same patterns are replicated at the regional scale within countries.

Later studies by Klier (1995, 1999, 2000) challenged the whole notion that JIT necessitates spatial proximity and geographic clustering. Klier (2000) argues that the level of spatial clustering exhibited in the Japanese automotive industry is nowhere near as high as Kenney and Florida (1992) suggest. The most geographically clustered supplier network identified by Klier (2000) was that of Honda. Only 29\% of Honda's suppliers are located within 100 miles of the assembly plant. Klier (2000) argued that JIT does not result in local scale geographic clustering. Rather, clusters of suppliers are more regional in nature, extending over hundreds of miles. Thus, the median distance between Auto Alliance (a joint venture between Mazda and Ford located in Flat Rock, Michigan) and its Japanese suppliers is 238 miles (Klier \& Rubenstein 2008a). Klier (1995, 1999), however, does note spatial clustering tendencies do seem to vary from automaker to automaker and according to whether the suppliers are domestic- or Japanese-owned. For example, Honda's supply network is more geographically clustered than Diamond Star's (a joint venture between Mitsubishi and Chrysler located in Normal, Illinois). Twentysix percent of Honda's Japanese suppliers are located within 100 miles, compared to only $8 \%$ of Diamond Star's Japanese suppliers. In a similar fashion, Japanese suppliers to the Japanese assembly plants tend to be more geographically clustered than domestic suppliers to the Japanese assembly plants. For example, $19 \%$ of Toyota's Japanese suppliers are located within 100 miles of the assembly plant. In contrast, only 5\% of Toyota's American suppliers are located within 100 miles of the assembly plant. Another important distinction noted by Kier and Rubenstein (2008b) is the difference in the mean distance between Japanese assembly plants and suppliers who are located in the northern and southern zones of the Auto Alley. The mean distance between assembly plants located in the northern zone of the auto alley (Illinois, Indiana, Kentucky, Michigan, and Ohio) ranges between 238 and 372 miles while the average distance in the southern zone (Alabama, Mississippi, and Tennessee) ranges between 497 and 776 miles. Japanese assembly plants located in the Auto Alley's southern zone are largely supplied by already established suppliers located in the Alley's northern zone. Southern zone assembly plants were constructed at later dates than those in the northern zone and automakers like Honda decided that this additional demand (e.g. for transmissions) could be met by northern zone suppliers. There are exceptions, of course. For example, Honda did build a new engine plant in close to proximity to its assembly plant in Lincoln, Alabama (Klier \& Rubenstein 2008a). An additional factor that influences the extent of geographic clustering between assemblers and suppliers is the nature of the parts being shipped. Parts that are bulky (e.g. transmissions and axles) and/or need to be produce in variety and in accordance in synchronicity with the assembly plant production schedule (e.g. seats) are best produced in close proximity to the customer (Klier 1998). Parts that are standardized and whose production can be planned well ahead of time can be manufactured at a greater geographic distance and still be delivered on a just-in-time basis This is often achieved by the use of third-party logistics providers who organize the delivery of various parts to distribution depots (crossdocks) where they are sorted and delivered to the assembly plant on a JIT basis. These distribution depots are located in close geographic proximity to the assembly facilities (Kaneko \& Nojiri 2008). Use of third-party 
logistics providers by the auto industry in the U.S. began in the early 1990s when many automakers realized that they could achieve both cost savings and higher levels of delivery reliability by utilizing the services of specialized logistics companies (Zielinski 2007). As a result the automotive industry is now the biggest user of third-party logistics providers in the United States (Carbone \& Soifer 2009). Toyota has become particularly adept at the use of cross-docking both within the United States and Japan (Liker \& Wu 2006; Kaneko \& Nojiri 2008). Cross-docking became particularly important in the post-2000 period when Japanese automobile assembly plants started to locate in the southern half of the Auto Alley (Fig. 1). In doing so they were locating geographically distant from many parts suppliers who were geographically concentrated in northern Auto Alley states such as Ohio and Indiana. The importance of appropriately experienced third-party logistics providers can best be exemplified by countries where they do not exist. Their absence is a major challenge for the Australian automotive industry (Singh et al. 2005).

In addition to cross-docking the nation's extensive Interstate Highway System facilitates the bridging of large geographic distances between suppliers and assemblers. Indeed geographic proximity to an Interstate Highway has been identified as a key locational determinant for Japanese automobile component parts makers (Kenney \& Florida 1992; Woodward 1992; Smith \& Florida 1995). There appears to be little debate on the literature on this issue. Indeed, Klier (2000) argues that geographic proximity to an Interstate Highway is more important than geographic proximity to assembly plants for Japanese auto parts makers. According to Akira Soejima, Senior Managing Director for Fuji Motors, a major reason that the automaker decided to build an assembly plant in Lafayette, Indiana was "because of its transportation facilities" (Perrucci \& Kong 1994: 41). In countries where a less modern and reliable highway system exists there are significant challenges to just-in-time delivery (Gulyani 2001).

\section{Labour}

The impact of labour as a locational determinant of JDIUSM has been investigated extensively in the geographic literature. Labour is a complex and multi-faceted site selection factor and brings to the surface a variety of issues including education, unionization, wage rates, and race. Doeringer and Terkla (1992) argue that labour force issues are the key to understanding the location decisions of Japanese manufacturers in the United States. Florida and Kenney (1991b, 392) on the other hand, in discussing Japanese direct investment in the automotive sector, argue that "the local labour market or local labor cost have relatively little impact on locational choices".

There seems to be general agreement in the literature that Japanese manufacturers place high value on employees who are flexible, loyal, and capable of engaging in problem solving (Doeringer \& Terkla 1992; Reid et al. 1995). Employees with such characteristics are considered critical to the successful introduction and smooth functioning of Japanese production methods. Japanese auto and auto parts makers with production facilities on the United States have a meticulous and rigorous process for hiring new employees (Florida \& Kenney 1991b).

Several studies have examined the role of trade unions in influencing the geography of JDIUSM. Both Woodward (1992) and Ó hUallacháin and Reid (1997) found evidence to support the hypothesis that the spatial distribution of Japanese greenfield plants are influenced by the desire to avoid states where trade unions are strong. Working at a different geographic scale (the county) and looking only at the role of three unions (the United Auto Workers, the United Steel Workers, and the United Rubber Workers) Smith and Florida (1994) found evidence that Japanese greenfield plants in the auto industry avoid counties where these three unions have a presence. Chang (1989), on the other hand, found no evidence that the location of right-to-work states have any influence on the spatial distribution of JDIUSM. 
In states with right-to-work laws unions tend to be weaker and have less influence as State law in those states prohibits membership of a trade union as a condition of employment. According to one regional development who worked for the state of Michigan Japanese automotive companies "try to get fifty or more miles out of reach from the union".

Doeringer and Terkla (1992) have argued that the existence of trade unions and/ or right-to-work laws is not critical in the location decisions of Japanese manufacturers. Rather, Japanese manufacturers seek locations where they can find labour who have the skills and commitment to engage in collaborative problem solving. Smith and Florida (1994) found that Japanese greenfield automotive investments are attracted to counties where the labour force is better educated and that Japanese auto parts makers have a tendency to locate in higher wage rate areas. They argue that this is consistent with the desire of Japanese auto part makers to hire workers who are better educated and have the problem solving skills and work ethic that they seek. In a letter sent to prospective employees one Japanese automaker stated that "we seek high morale and motivation among all employees (...), we will pay you a competitive wage. In return we expect excellent attendance, high productivity, and the best quality work from you" (Mills 1985).

The role of race in influencing JDIUSM has also been investigated in the geographic literature. The identification of race as a potential locational determinant of JDIUSM was prompted partly by anecdotal evidence that Japanese manufacturers prefer to avoid locations with large minority populations and partly by a number of lawsuits in the early 1980s in which Honda was accused of utilizing hiring practices that discriminated against Blacks and females (Cole \& Deskins 1988). A local government official in a midwestern state who helped to recruit Japanese investment to his state during the 1980s noted that "many Japanese companies at the time specifically asked to stay away from areas with high minority populations" (Cole \& Deskins
1988). The evidence on race is mixed. Woodward (1992) found that Japanese greenfield plants in the Auto Alley avoided counties with high Black population densities. He found no such evidence of similar avoidance for Japanese greenfield plants located outside of the Auto Alley. In a later study, however, Smith and Florida (1992) present evidence that refutes the notion that Japanese greenfield automotive investments avoids counties with large minority (non-white) populations.

Japanese labor preferences have resulted in many Japanese manufacturers opting for greenfield plants in rural locations and small towns. Over half of Japanese automotive plants are located in towns whose populations are under 20,000 (Reid 1990; Florida \& Kenney 1991a). It is in such locations that the 'right type' of employee can be found. Cole and Deskins (1988) also argue that small towns and rural locations facilitate the Japanese's racist hiring policies. The Equal Employment Opportunity Commission (EEOC) requires the racial composition of a manufacturing plant's workforce be representative of the plant's labourshed. Cole and Deskins (1988) suggest that locating in predominantly White small towns allows Japanese automotive companies to hire small numbers of Blacks without violating EEOC guidelines. Despite locating in such communities Cole and Deskins (1988) found that Japanese automotive companies still hired a smaller percentage of Blacks than mandated by EEOC guidelines.

Labour has also impacted the location decisions of Japanese automakers in terms of where they locate with respect to each other. Japanese automakers do not wish to compete with each other for the same potential labour force. Initially they avoided such competition by locating in a different state from other Japanese automakers. With only eight states in the auto alley, however, each one soon had a Japanese automobile assembly plant and the automakers had to locate in the same state as a competitor. In choosing locations Japanese automakers strategically located at least a twohour drive from an existing Japanese automobile assembly plant (Klier \& Rubenstein 2008b). 


\section{Conclusions and future research}

This chapter has provided a summary of several decades of research on the geography of Japanese direct investment in the U.S. manufacturing sector. Much of the early geographic literature on JDI in the U.S. automotive industry suggested that JIT necessitates close geographic proximity between suppliers and customers. The result is a geographically concentrated supply network in which automobile assembly plants are surrounded by literally dozens of component parts makers. More recent writings, however, call into question this suggested geographic arrangement and evidence has been presented which suggests that supply networks extend over hundreds of miles and are regional, rather than local, in nature. These supply networks became more geographically dispersed as new Japanese automobile assembly plants opened up in southern states in the post-2000 period. These new plants were geographically distant from already existing suppliers located in northern states. In many respects, it is somewhat ironic that scholarly interest in the geography of Japanese direct investment in the U.S. automotive sector waned at a time (post-2000) when the emergence of plants in southern states was actually making the spatial dynamics of the industry more interesting.

Part of the early rush to judgment as to the spatial implications of JIT may stem from misconceptions, on the part of economic geographers, as to the nature of JIT. Lubben (1988) (not a geographer) notes that one of the major misconceptions about JIT is that it is primarily an inventory control system. While inventory reduction is a potential benefit of JIT it is one of a number of objectives. As noted by Lubben (1988: 8) "the goal of JIT is to eliminate any function in the manufacturing system which burdens the company with overhead, impedes productivity, or adds unnecessary expense to the customer's operating system". From this definition it is clear that minimizing inventory is just one unnecessary expense that might exist in any manufacturing system. Economic geographers seemed overly-focused on the idea that inventory control is the primary objective of JIT. Much of the early writings about the geographic implications of JIT were predicated on this idea. It may have, therefore, benefitted geographers to delve more deeply into the business school literature and develop a more comprehensive understanding of JIT. It is also highly probable, given the lack of any reference to it in the literature, that geographers were unaware of the emergence and utilization of third party logistics providers and crossdock distribution points which allowed some parts to be delivered on a just-in-time basis from a longer geographic distance.

It is, of course, possible that there is some merit to the close geographic proximity hypothesis postulated by the earlier writings. One of the problems associated with the manner in which economic geographers have dealt with the issue of the spatial implications of JIT revolves around the fact that JIT, from an inventory control perspective, is ill defined. Many manufacturers claim that they have material inputs delivered on a JIT basis. However, JIT delivery means different things to different manufacturers. For example, research by Delbridge and Oliver (1991) and Liker and Lu (2006) suggests that there is a considerable gap between the relative efficiencies of the JIT systems of American and Japanese manufacturers. For example in their study, of 54 automobile component parts suppliers in Japan, the United States, and Europe who claimed to utilize JIT inventory control, revealed that Japanese suppliers had average of 1.52 days of inventory and 7.9 deliveries per day. American suppliers, on the other hand, had an average of 8.1 days of inventory and 1.5 deliveries per day. This general pattern has been verified by Liker and Wu (2006) who demonstrate that Japanese automakers in the United States perform much better than their American counterparts when it comes to the efficiency of JIT - this includes inventory turnover, the need to use emergency deliveries, and on-time arrival of shipments. Clearly, this suggests that JIT can be operated 
at different levels of efficiency. More research in this area would be both informative and enlightening.

Beyond addressing the questions arising from the spatial implications of JIT there is clearly room for expanding studies of JDIUSM beyond the automotive sector. While the emphasis on the automotive sector is understandable there is ample Japanese direct investment in other manufacturing sectors that are worthy of attention, e.g. chemicals, industrial machinery, and electronic products. We know very little about JDI in these other manufacturing sectors. Many of the same questions and issues that have been asked and raised with respect to JDI in the automotive sector could be applied to these other sectors. What are the locational determinants of JDIUS in these other sectors? How extensively is JIT used in these sectors?

Researchers also need to think carefully about the appropriate scales of analysis for enhancing our understanding of the geography of JDIUSM. Much of our scales of analysis decisions are driven by data availability. Thus, the state and the county have been popular units of analysis. As noted above, however, a number of studies suggest that agglomeration economies are regional, rather than local, in nature. This leads Head et al. (1994) to question whether the state is the appropriate geographic unit

\section{References}

Allen J.P., Turner E., 1996. Spatial patterns of assimilation. Professional Geographer, vol. 48, no. 2, 140-155.

BeLLI R.D., 1984. Foreign Direct Investment in the United States in 1983. Survey of Current Business, vol. 64, no. 10, pp. 26-48.

Blonigena B., Ellis C.J., Fausten D., 2005. Industrial groupings and foreign direct investment. Journal of International Economics, vol. 65, no. 1, pp. 75-91.

Bureau of Economic Analysis, U.S. Department of COMmerCe, 1986. Foreign direct investment of investigation. The decision as to what is the appropriate geographic scale of investigation needs to be driven by theory rather than by the availability of data. Circumventing data limitations problems might require the utilization of more sophisticated analytical techniques and/or the collection of primary survey data.

Finally, there appears to have been a general decrease in scholarly interest in Japanese direct investment since the late 1990s. This, to a large extent, appears to mirror a declining scholarly interest about the topic of foreign direct investment in the United States in general. It may well be that scholars feel that there is little interest in the topic among their peers. There is a tendency in academia for topics to go through a life cycle characterized by increasing interest, peak interest, and declining interest. In that respect JDIUSM is perhaps no different than many other topics in economic geography. That does not mean, however, that the topic is irrelevant or unimportant. Despite declining academic interest Japanese direct investment in the U.S. manufacturing sector continues to grow and is worthy of ongoing monitoring and study.

\section{Editors' note:}

Unless otherwise stated, the sources of tables and figures are the author(s), on the basis of their own research.

in the United States: Detail for historical-cost position and balance of payments flows, 1985. Survey of Current Business, vol. 66, no. 8, pp. 74-86.

Bureau of Economic Analysis, U.S. Department OF COMMERCE, 1988. Foreign direct investment in the United States: Detail for historical-cost position and balance of payments flows, 1987. Survey of Current Business, vol. 68, no. 8, pp. 69-83.

Bureau of Economic Analysis, U.S. Department OF COMMERCE, 1991. Foreign direct investment in the United States: Detail for historical-cost position and balance of payments flows, 1990. Survey of Current Business, vol. 71, no. 8, pp. 47-79. 
Carbone L., Solfer D., 2009. Third-party logistics: Keeping America's economy moving. Arlington, VA: Lexington Institute.

CHANG, K-T., 1989. Japan's direct manufacturing investment in the United States. The Professional Geographer, vol. 41, no. 3, pp. 314-328.

Cole R.E., Deskins D.T., 1988. Racial factors in site location and employment patterns in Japanese auto firms in America. California Management Review, vol. 31, no. 1, pp. 9-22.

Crozet M., Mayer T., Mucchielli J.-L., 2004. How do firms agglomerate? A study of FDI in France. Regional Science and Urban Economics, vol. 34, no. 1, pp. 27-54.

Delbridge R., Oliver N., 1991. Narrowing the gap? Stock turns in Japanese and western car industries. International Journal of Production Research, vol. 29, no. 10, pp. 2083-2095.

DICKEN P., 1988. The changing geography of Japanese foreign direct investment in manufacturing industry: A global perspective. Environment and Planning A, vol. 20, no. 5, pp. 633-653.

Doeringer P.B., TerkLA D.G., 1992. Japanese direct investment and economic development policy. Economic Development Quarterly, vol. 6, no. 3, pp. 255-272.

Elhance A., Chapman M., 1992. Labor market of a U.S.-Japanese automobile joint venture. Growth and Change, vol. 23, no. 2, pp. 160-182.

FloRida R., Kenney M., 1991a. Japanese foreign investment in the United States: The case of automotive transplants [in:] J. Morris (ed.), Japan and the Global Economy: Issues and trends in the 1990s. London: Routledge, pp. 91-114.

Florida R., Kenney M., 1991b. Transplanted organizations: The transfer of Japanese industrial organization to the US. American Sociological Review, vol. 56, no. 3, pp. 381-398.

Florida R., Kenney M., 1992. Restructuring in place: Japanese investment, production, and the geography of steel. Economic Geography, vol. 68, no. 2, pp. 146-173.

FlynN M.S., 1986. Currencies and competition: Implications for Michigan suppliers. AIM (Auto in Michigan) Newsletter, vol. 2, no. 1, pp. 1-4.

FrANKO L.G., 1983. The threat of Japanese multinationals: How the west can respond. New York: John Wiley and Sons.

Gross N., 1989. Taking on Japan: Why US business wants backup. Business Week, 13 November.
Gross D.M., Raff H., Ryan M., 2005. Inter- and intra-sectoral linkages in foreign direct investment: Evidence from Japanese investment in Europe. Journal of the Japanese and International Economies, vol. 19, no. 1, pp. 110-134.

GulyanI S., 2001. Effects of poor transportation on lean production and industrial clustering: Evidence from the Indian auto industry. World Development, vol. 29, no. 7, pp. 1157-1177.

HAIGH R.W., 1989. Investment strategies and the plant-location decision: Foreign companies in the United States. New York: Praeger.

HE C., 2003. Location of foreign manufacturers in China: Agglomeration economies and country of origin effects. Papers in Regional Science, vol. 82 , no. 3, pp. 351-372

HeAd K., Ries J., Swenson D., 1995. Agglomeration benefits and location choice: Evidence from Japanese manufacturing investments in the United States. Journal of International Economics, vol. 38, no. 3-4, pp. 223-247.

Heller H.R., Heller E.E., 1974. Japanese investment in the United States. New York: Praeger Publishers.

IbarRa-Caton M., 2013. Direct investment for 2009-2012: Detailed historical-cost positions and related financial and income flows. Survey of Current Business, 93, pp. 200-284.

KAneko J., NojirI W., 2008. The logistics of justin-time between parts suppliers and car assemblers in Japan. Journal of Transport Geography, vol. 16, no. 3, pp. 155-173.

KaWAHITO K., 1981. Japanese steel in the American market: Conflict and causes. The World Economy, vol. 4, no. 2, pp. 229-250.

Kenney M., FloRida R., 1991. How Japanese industry is rebuilding the rustbelt. Technology Review, vol. 94, no. 2, pp. 24-33.

Kenney M., Florida R., 1992. The Japanese transplants: Production organization and regional development. Journal of the American Planning Association, vol. 58, no. 1, pp. 21-38.

KLIER T.H., 1995. The geography of lean manufacturing: Recent evidence from the U.S. auto industry. Economic Perspectives, vol. 19, no. 6, pp. 2-16.

KLIER T.H., 1998. Geographic concentration in U.S. manufacturing: evidence from the U.S. auto supplier Industry. Federal Reserve Bank of Chicago Working Paper, no. WP-98-17. 
KLIER T.H., 1999. Agglomeration in the U.S. auto supplier industry. Economic Perspectives, vol. 23, no. 1, pp. 18-34.

KLIER T.H., 2000. Does "just-in-time" mean right next door?: Evidence from the auto industry on the spatial concentration of supplier networks. Journal of Regional Analysis and Policy, vol. 30, no, 1, pp. 41-57.

Klier T.H., Rubenstein J.M., 2008a. The closely linked supply chain [in:] T.H. Klier, J.M. Rubenstein, Who really made your car?: Restructuring and geographic change in the auto industry. Kalamazoo, Michigan: W.E. Upjohn Institute for Employment Research, pp. 135-158.

Klier T.H., Rubenstein J.M., 2008b. Emergence of auto alley [in:] T.H. Klier, J.M. Rubenstein, Who really made your car?: Restructuring and geographic change in the auto industry. Kalamazoo, Michigan: W.E. Upjohn Institute for Employment Research, pp. 205-227.

KNiCKerbocker F., 1973. Oligopolistic reaction and multinational enterprise. Boston: Graduate School of Business Administration. Harvard University.

Kotabe M., Martin X., Domoto H., 2003. Gaining from vertical partnerships: Knowledge transfer, relationship duration, and supplier performance improvement in the U.S. and Japanese automotive industries. Strategic Management Journal, vol. 24, no. 4, pp. 293-316.

LEWIS G., 1989. Computers: Japan comes on strong. Business Week, 23 October, pp. 104-107, 110, 112.

LIKER J.K., WU, Y.-C., 2006. Japanese automakers, US suppliers and supply chain superiority [in:] E. Rhodes, J.P. Warren, R. Carter, Supply chains and total product systems: A reader. Malden, MA: Blackwell, pp. 177-194.

LOWE J.H., 1998. Foreign direct investment in the United States: Detail for historical-cost position and related capital and income flows, 1997. Survey of Current Business, vol. 78, no. 9, pp. 74-110.

LOWE J.H., 2001. Foreign direct investment in the United States: Detail for historical-cost position and related capital and income flows, 2000. Survey of Current Business, vol. 81, no. 9, pp. 40-78.

LOWE J.H., 2004. Foreign direct investment in the United States: Detail for historical-cost position and related capital and income flows, 2003. Survey of Current Business, vol. 84, no. 9, pp. 61-99.
LOWE J.H., 2007. Foreign direct investment in the United States: Detail for historical-cost position and related capital and income flows. 2004-2006. Survey of Current Business, vol. 87, no. 9, pp. 33-73.

LOWE J.H., 2011. Direct investment for 2007-2010: Detailed historical-cost positions and related financial and income flows. Survey of Current Business, vol. 91, no. 9, pp. 50-137.

LUBBEN R.T., 1988. Just-in-time manufacturing. New York: McGraw-Hill.

MACKNIGHT S., 1989. Japan's expanding US manufacturing presence: 1988 update. Washington, D.C.: Japan Economic Institute.

Mair A., Florida R., Kenney M., 1988. The new geography of automobile production: Japanese transplants in North America. Economic Geography, vol. 64, no. 4, pp. 352-373.

Martin X., Mitchell W., Swaminathan A., 1995. Recreating and extending Japanese automobile buyer-seller links in North America. Strategic Management Journal, vol. 16, no. 8, pp. 589-619.

MilLs D.Q., 1986. The new competitors. New York: John Wiley \& Sons.

NGIDO M., 2011. Understanding and predicting the foreign direct investment behavior of ancillary firms: The case of Japanese ancillary firms affiliated with Mazda Motor Corp. The Economic Review, vol. 62, no. 2-3, pp. 267-311.

Ó HUALLACHÁIN B., 1993. The restructuring of the US steel industry: Changes in the location of production and employment. Environment and Planning A, vol. 25, no. 9, pp. 1339-1359.

Ó hUallaCháln B., ReID N., 1992. Source country differences in the spatial distribution of foreign direct investment in the United States. The Professional Geographer, vol. 44, no. 3, pp. 272-285.

Ó hUallacháin B., Reid N., 1997. Acquisition versus Greenfield investment: the location and growth of Japanese manufacturers in the United States. Regional Studies, vol. 31, no. 4, pp. 403-416.

OzAWA T., 1979. Multinationals Japanese style: The political economy of outward dependency. World Politics, vol. 30, no. 4, pp. 517-537.

Perrucci R., Kong F., 1994. Settling in the heartland: Why the Midwest corridor? [in:] R. Perrucci (ed.), Japanese auto transplants in the heartland: Corporatism and community. New York: Aldine de Gruyter, pp. 41-75. 
ReID N., 1990. Spatial patterns of Japanese investment in the US automobile industry. Industrial Relations Journal, vol. 21, no. 1, pp. 49-59.

REID N., 1991. Japanese direct investment in the United States manufacturing sector [in:] J. Morris (ed.), Japan and the Global Economy: Issues and Trends in the 1990s. London: Routledge, pp. 61-88.

REID N., 1995. Just-in-time inventory control and the economic integration of Japanese-owned manufacturing plants with the county, state, and national economies of the United States. Regional Studies, vol. 29, no. 4, pp. 345-355.

Reid N., Ó hUallacháin B., 1990. Comments on "Japan's direct manufacturing investment". The Professional Geographer, vol. 42, no. 2, pp. 223-226.

Reid N., Solocha A., Ó hUallacháin B., 1995. Japanese corporate groups and the locational strategy of Japanese auto and component parts makers in the United States [in:] M.B. Green, R. McNaughton (eds.), The location of foreign direct investment: Geographic and business approaches. Aldershot: Avebury, pp. 107-120.

RubensteIN J.M., 1986. Changing distribution of the American automobile industry. The Geographical Review, vol. 76, no. 3, pp. 288-300.

RubensteIn J.M., 1991. The impact of Japanese investment in the United States [in:] C. Law (ed.), Restructuring the global automobile industry. London: Routledge, pp. 114-142.

SAYER A., 1986. New developments in manufacturing; the just-in-time system. Capital and Class, vol. 10, no. 3, pp. 43-72.
Shaver J.M., Flyer F., 2000. Agglomeration economies, firm heterogeneity, and foreign direct investment in the United States. Strategic Management Journal, vol. 21, no. 12, pp. 1175-1193.

Singh P.J., Smith A., Sohal A.S., 2005. Strategic supply chain management issues in the automotive industry: An Australian perspective. International Journal of Production Research, vol. 43, no. 16 , pp. 3375-3399.

SMith D., Florida R., 1994. Agglomeration and industrial location: An econometric analysis of Japanese-affiliated manufacturing establishments in automotive-related industries. Journal of Urban Economics, vol. 36, no. 1, pp. 23-41.

TREVOR M., 1983. Japan's reluctant multinationals: Japanese management at home and abroad. New York: St. Martin's Press.

TSUKAZAKI S., 1987. Japanese direct investment abroad. Journal of Japanese Trade and Industry, 4, pp. 10-15.

TYEBJEE T.T., 1988. A typology of joint ventures: Japanese strategies in the United States. California Management Review, vol. 31, no. 1, pp. 75-86.

WoOdWARD D.P., 1992. Locational determinants of Japanese manufacturing start-ups in the United States. Southern Economic Journal, vol. 58, no. 3, pp. 690-708.

Yoshino M.Y., 1976. Japan's multinational enterprises. Cambridge: Harvard University Press.

ZeLINKSKI K., 2007. Evolving third-party logistics in the auto industry. Area Development Online, http://www.areadevelopment.com/specialPub/ auto07/autoEvolvingThirdParty.shtml [15 June 2014]. 